\title{
The influence factors of job satisfaction and its relationship with turnover intention: Taking early-career employees as an example
}

\author{
Xianyin Lee ${ }^{1}$, Boxu Yang ${ }^{2 *}$ and Wendong $\mathrm{Li}^{3^{*}}$ \\ 1 School of Management Qufu Normal University, Rizhao, 276826 (China). \\ 2 Business School, University of International Business and Economics, Beijing, 100029 (China). \\ 3 School of Statistics, East China Normal University, Shanghai, 200241 (China).
}

\begin{abstract}
Título: Los factores que influyen en la satisfacción en el trabajo y su relación con la intención de baja laboral: tomando a los empleados que inician su carrera como ejemplo.

Resumen: La satisfacción en el trabajo en empleados que inician su carrera tiene un efecto significativo en la conducta laboral y en la actitud ante el trabajo en los empleados. Este estudio investiga los factores que influyen en la satisfacción en el trabajo y su relación con el bajas laborales. Se seleccionaron empleados en su fase inicial como sujetos de investigación. Se distribuyeron cuestionarios según un método de muestreo aleatorizado estratificado para analizar 418 muestras recogidas. Las dimensiones de la satisfacción en el trabajo fueron analizadas mediantes análisis factorial exploratorio y análisis factorial confirmatorio, y con ello se construyó un modelo de ecuaciones estructurales para discutir la relación entre satisfacción en el trabajo y los motivos de bajas laborales. Primero, para empleados iniciales, la satisfacción en el trabajo como factor de orden superior consistía en seis factores de primer orden; la influencia del desarrollo personal en la satisfacción en el trabajo fue la mayor, con un coeficiente path de .918. El siguiente fue el salario y el bienestar, el trabajo por sí mismo, las relaciones interpersonales y la conducta de liderazgo. Adicionalmente, la competencia laboral tuvo un efecto mínimo sobre la satisfacción en el trabajo; su coeficiente path es sólo .214. En segundo lugar, la satisfacción en el trabajo tuvo un efecto significativamente negativo sobre los motivos de baja laboral, indicando que la estructura de satisfacción en el trabajo de los empleados iniciales tiene características propias, puesto que ellos se centran más en el desarrollo personales y el espacio de desarrollo. Mejorando la satisfacción laboral, la conducta de baja laboral de los empleados iniciales puede ser controlada efectivamente.

Palabras clave: Satisfacción en el trabajo; recursos humanos; desarrollo personal; conducta laboral; empleados.
\end{abstract}

\section{Introduction}

Job satisfaction is a term first advanced by scholar Hoppock (1935) who defines job satisfaction as the psychological and physiological aspects of employees' satisfaction with job environmental factors, in other words, as employee subjective responses to the working environment. Based on this definition, psychology, organizational behavior and sociology scholars advanced their own views (Vroom, 1962; Kalleberg \& Loscocco, 1983; Richard, Joseph, \& Billy, 2001).

Patricia, Rebecca and Jane (2016) use survey data from a cohort study of nursing students recruited through two Australian universities. Results show that two job satisfaction sub-scales were identified: 1) work environment satisfaction and 2) work hours and wages satisfaction. Work preparation satisfaction was significantly and positively associated with both job satisfactions, but only work environment satisfac-

* Correspondence address [Dirección para correspondencia]:

Boxu Yang. Business School, University of International Business and Economics, Beijing, 100029 (China).E-mail: boxu911@163.com

Wendong Li School of Statistics, East China Normal University, Shanghai 200241, (China).E-mail: liwendong1994@126.com
Abstract: Job satisfaction of early-career employees has a significant effect on employee work behavior and work attitude. This study investigated the influence factors of job satisfaction and its relationship with turnover intention. Early-career employees were selected as the research subject. Questionnaires were distributed and the stratified random sampling method was used to analyze the 418 samples collected. The dimensions of job satisfaction were analyzed by exploratory factor analysis and confirmatory factor analysis, and a structural equation model was constructed to discuss the relationship between job satisfaction and turnover intention. First, for early-career employees, job satisfaction as a higher order factor consists of 6 first-order factors; personal growth's influence on job satisfaction is the greatest, with a path coefficient reaching .918 . Next come salary and welfare, work itself, interpersonal relationships and leader behavior. Additionally, job competency has a minimal effect on job satisfaction; its path coefficient is only .214. Second, job satisfaction has a significantly negative effect on turnover intention, indicating that the job satisfaction structure of early-career employees has its unique characteristics because they focus more on personal growth and development space. Through improving job satisfaction, turnover behavior of early-career employees can be effectively controlled.

Key words: Job satisfaction; human resources; individual growth; work behavior; employee. tion was significantly associated with the expectation to stay in the job. Risman, Rebecca et. al (2016) found that nurses' perceived person-organization fit is a significant predictor of general job satisfaction. Isabel and Eva (2016) used HLM method to examines the simultaneous effect of individual (self-efficacy) and group variables (cohesion and gender diversity) on satisfaction. The results of the HLM show that self-efficacy has a direct and positive effect on individual satisfaction also a cross-level effect of group cohesion and gender diversity on satisfaction appeared. According to Byron, Jing and Johanna (2016) work hour congruence has a significant and positive effect on satisfaction, that is to say, a difference between employees who desire more hours and those who desire fewer hours: employee desire for and receipt of more hours was related to positive changes in job satisfaction, while employee desire for and receipt of fewer hours was related to reduced absenteeism .Alina and Simona (2013) studied the influence factors of university teachers' job satisfaction, showing that job satisfaction of college teachers is influenced by factors such as wage, promotion criteria, working conditions, promotion, colleagues, and school policy. Chen (2015) suggest that in practical work the 
ingratiation involved leadership, colleagues and self perception were the factors of job satisfaction etc. which effect employee's job satisfaction. His empirical study of 301 manufacturing employees showed that ingratiation behavior has a negative impact on satisfaction.

For modern enterprises, having employees with higher job satisfaction often means a lower staff turnover rate (Porter, Steers, Mowday \& Boulian, 1974; Scanlan \& Still, 2013; Shen \& Zhu, 2012). Relevant empirical studies have confirmed this view. For example, Wang and Zhang (2010) discovered that job satisfaction has a negative influence on turnover intention. Using 383 construction-enterprise employees as subjects, Xiong, Sun, and Koo (2008) found a significant correlation between job satisfaction and organizational identification and turnover intention. Scanlan and Still (2013) found that higher job satisfaction could result in lower job burnout and turnover intention. Starting from the individual perceptions of knowledge workers, Peng (2008) found that their job satisfaction is negatively correlated with turnover intention.

Job satisfaction of early-career employees is an important factor that affects turnover intention (Vermeeren, Kuipers, \& Steijn, 2014; Fachrunnisa, Adhiatma, \& Mutamimah, 2014). The early-career stage is the process by which a person gradually becomes "organized" within the organization and is gradually accepted by the organization. In the early stages of a career, employees generally have the following characteristics: First, they are aggressive and positive but easily impetuous and impulsive; they aim too high. Second, they work independently but are reluctant to obey orders and follow instructions. Third, their experience is insufficient, their career anchors are not stable, and they are quick to leave. The above characteristics put early-career employees in a position such that in the "professionalizing" process, they will encounter conflicts with the external environment, internal groups and other individuals and will meet with difficulties. These problems need to be solved timely and effectively or they will easily induce employee dissatisfaction (Melinde \& Nisha, 2014), which reduces job satisfaction and may lead to turnover. By studying new nurses, Laschinger (2012) found that job satisfaction has a significantly negative effect on turnover intention. Through a questionnaire survey of employees in 101 high-tech enterprises, Li (2009) found that a higher degree of trust from top management was associated with a lower employee turnover intention. The study of Wang, Ma, and Zhang (2014) revealed that the turnover tendency for the post-80s only-child generation is more obvious than that of the non-only-child counterparts. Early-career employees are of crucial importance for an enterprise to maintain its vitality and a healthy and steady development. However, voluntary turnover of early-career employees can result in an increase in the costs of enterprise staff training and human resource replacement, and it can reduce the operating efficiency of the enterprise. Although scholars have discussed the influencing factors of Chinese employees' job satisfaction from different perspectives, the factors that in- fluence job satisfaction of early-career employees, which is an important career group, and the relationship between job satisfaction and turnover intention have not received due attention from academia. At the same time, because of the influence of industry, enterprise cultural background and other factors, at present there is not a unified view concerning the relationship between early-career employees' job satisfaction and their turnover intention. To solve this problem, it is necessary to make a systematic study of early-career employees in additional industries.

Nowadays, post-1980s and post-1990s generation employees have begun to board the stage of history, and gradually become the main force in the workplace. They are generally 18 to 35 years old, according to the theory of career, is in the early stages of career. On one hand, these people who

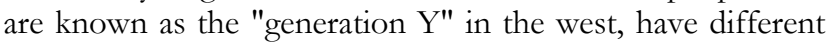
characters such as diversified career ideal, high mobility, willing to accept challenging work and paying attention to the balance of work and life than their predecessors (Zhou, 2009). Such characteristics of the "generation Y" are challenges to the existing management model. On the other hand, with the disappearance of the "demographic dividend", the acceleration of the process of population aging has prompted China to usher in a historical turning point in the negative growth of the working age population (Wang, 2012). Therefore, there is an important significance for the enterprises to fully understand the early career employee, and improve their job satisfaction through institutional innovation and management innovation.

To sum up, due to the special background of China and the characteristics of the early career employee, it is of theoretical and practical significance to study the influencing factors of enterprise employees' job satisfaction and the relationship between job satisfaction and turnover intention in their early career.

To ensure representativeness of the samples, this study selected employees in their early career who are engaged in such industries as communication services, financial services, petrochemical processing, and manufacturing enterprises as research subjects. The study investigated job satisfaction using exploratory factor analysis and confirmatory factor analysis. Then, it constructed a structural equation model of job satisfaction and turnover intention and explored the influencing mechanism of job satisfaction on turnover intention.

\section{Early career}

Concerning the classification of the early stages of a career, scholars have conducted studies from different perspectives. Focusing on the main task of career development, Greenhause (1987) classified early career as the age range from 25 to 40. Hall and Mansfield (1975) thought the early stage of a career starts at 20 and ends at 34. Scholars in the past often classified career according to age, job position and working state. With economic development and social progress, due to differences in employee working experience 
and career path, this type of simple classification cannot meet the today's need for more complete information. Drawing on the above-mentioned two classification methods, based on the age when employees began a career for the first time, this study classified the time marker for the early stage of career as a length of service of 10 years or less.

\section{Job satisfaction and its influencing factors}

When using the job elements comprehensive scoring method, scholars hold different views of the structure of job satisfaction. An often-used method is the Minnesota Satisfaction Questionnaire (MSQ), which classifies job satisfaction into four main aspects: work itself, interpersonal relationships on the job, reward and development (Weiss, Dawis \& England, 1967). Psychologists Smith (1969) advance Job Descriptive Index (JDI), which includes 5 key dimensions: work itself, pay, supervision, promotions and promotion opportunities, and coworkers. Justin and Meganet (2013) suggest that burnout was associated with lower job satisfaction and higher job satisfaction was associated with rewards (remuneration and recognition) as well as cognitively challenging work. Inés, Marta and Jasmina (2016) revealed that three different paths could explain job satisfaction: (1) teamwork, identification with the strategy, and the absence of employee work-family balance; (2) employee work-family balance, autonomy, and identification with the strategy; and (3) supervisor support and identification with the strategy. Chinese scholars have conducted domestic studies of the dimensions of job satisfaction. Liu studied the job satisfaction of employees in private enterprises and found that "training and development", "top management", "department" and "customer service" have a rather large influence on employees' job satisfaction, whereas "direct manager", "salary and welfare" and "work objectives and performance" have almost no influence on job satisfaction. Through analyzing previous scholars' scales, Zhang and Liao (2007) proposed a fivedimension model for job satisfaction. The scale includes satisfaction with work itself, superior, relationships with colleagues, promotion and pay. Liu, Wang, Liu, and Wei (2013) found that there is a positive influence between employee relations and job satisfaction. Basing on the ERG and job satisfaction theory, Li, Wang and Chen (2015) built the job satisfaction system of New Generation Faculty in University which included growth need, existence need and relationship need. Based on the MSQ and a large-scale interview of employees in China, and combined with domestic studies on job satisfaction, this study defined the influencing factors of job satisfaction of early-career employees as salary and welfare, leader behavior, work itself, interpersonal relationships, job competency and personal growth, and this study posits the following hypotheses:

H1a: Salary and welfare is positively related to job satisfaction in the early career;

H1b: Leader behavior is positively related to job satisfaction in the early career;
H1c: Work itself is positively related to job satisfaction in the early career;

H1d: Interpersonal relationships is positively related to job satisfaction in the early career;

H1e: Job competency is positively related to job satisfaction in the early career;

H2f: Personal growth is positively related to job satisfaction in the early career.

\section{Job satisfaction and turnover intention}

Since the 1970s, industrial psychologists have focused on the issue of employee turnover from a microscopic angle. To study turnover intention, scholars primarily focus on the relationship between turnover intention and its predictive variables. A general review of scholars' research fruits reveals that variables such as job satisfaction, organizational trust, managerial support, and organizational justice all have an obvious predictive role for turnover intention. Meisler (2013) discovered that emotional quotient has a significantly positive influence on organizational justice and a significantly negative influence on turnover intention. Furthermore, organizational justice plays a full mediating role in the influence of emotional quotient on turnover intention.

Quite a few studies show that employee job satisfaction has a significantly negative influence on turnover intention (Esra, Ümit, Serhat, \& Kültigin, 2013; Faris, Mary, Scott, \& Joyce, 2014); that is, higher job satisfaction is associated with lower turnover intention. There has been a variety of achievements by theoretical studies into job satisfaction and turnover intention and their correlation. However, there remain some limitations. Most available literature focuses on the comprehensive study of the relationship between job satisfaction and turnover intention, whereas there is little literature with early-career employees as research subjects. Taking early-career employees as research subjects, this study conducted an empirical study of the relationship between the job satisfaction of early-career employees and their turnover intention, and proposes the following hypothesis:

$\mathrm{H} 2$ : Job satisfaction is negatively related to turnover intention. in the early career.

\section{Method}

\section{Participants}

To improve the extensiveness and representativeness of the research, this study selected early-career employees engaged in, for example, communication services, petrochemical processing, and manufacturing industries as research subjects. We selected 30 enterprises of different industries, natures and scales in Shandong Province, Shanghai, and Jiangsu Province. To improve accuracy, the subjects were told before the survey that the survey results are to be used for academic study only, and the survey was conducted in a secretballot manner. With the help of personnel from the enter- 
prises' human resources departments, the questionnaires were distributed to employees of various departments using the stratified random sampling method, and special recycling bins were set up to recover the questionnaires.

\section{Measures and Tools}

Two variables were involved in this study, namely job satisfaction and turnover intention. Job satisfaction includes six dimensions: satisfaction with salary and welfare, work itself, leader behavior, personal growth, interpersonal relationships, and job competency. This study adopted the Likert scale, which was divided into 5 levels, i.e., "Strongly agree", "Disagree", "Neither agree nor disagree", "Agree" and "Strongly agree"; these levels were assigned 1 to 5 points, respectively. To avoid common method variance, some reverse problems were provided in the scale. After data collection, the corresponding data were treated with the reverse processing.

\section{Job Satisfaction}

According to the job satisfaction six-factor model proposed in this paper, the job satisfaction scale for early-career employees' job satisfaction was formulated with 35 items (See Supplementary Table 1) and included six subdimensions to measure salary and welfare, work itself, leader behavior, personal growth, interpersonal relationships and job competency. Among the 35 items were salary and welfare, which includes six items such as "A13: I feel my work has been duly rewarded" and "A32: I feel satisfied about my opportunity for a pay rise". Work itself includes six items such as "A14: I can derive pleasure from my job" and "A35: I like my current job very much". Leader behavior includes six items such as "A4: My superior is very capable" and "A11: I like my superior". Personal growth includes five items such as "A16: I feel satisfied with my promotion opportunity" and "A17: I can constantly get new knowledge and experience from my work". Interpersonal relationships includes 6 items such as "A12: There is a lot of responsibility-shirking and bickering in the workplace (R)" and "When pressures and difficulties arise in my work, my colleagues can offer me help and support". Job competency includes five items such as "A25: The operation procedure of the company has made me very exhausted (R)" and "A19: My work pressure makes me have no time to do what I want". The overall Cronbach's alpha reliability coefficient of the job satisfaction scale was .925.Cronbach's alpha for the 6 dimensions of job satisfaction, namely salary and welfare, work itself, leader behavior, job competency personal growth, and interpersonal relationships were $.796, .823, .529, .762$, and .765 .

\section{Turnover intention}

The study designed a single-dimension scale by referring primarily to the turnover scales created by Griffeth and Horn (1988) and Mobley (1978), which are widely recognized in academic circles. The scale includes four items such as "I consider leaving my current enterprise one day" and "I think my own prospects might not be good if I continue to stay in the company" (Supplementary Table 1). Cronbach's alpha for this scale was .874

\section{Implementation of the Survey}

\section{Pre-survey}

To ensure the reliability and validity of the scale used in this paper, a pre-survey was conducted before the formal survey. We selected 20 enterprises in communication, petrochemical processing and manufacturing industries in Shandong Province, Shanghai, and Jiangsu Province. With the help of personnel from the enterprises' human resources departments, we selected 130 employees who were under 30 as subjects, and to improve accuracy, the subjects were told that the survey results were to be used only academically, and the pre-survey was conducted in the secret-ballot manner. The pre-survey subjects included 61 male employees and 69 female employees, with $71.5 \%$ having a high school education or above.

SPSS 20.0 statistical software was used to test the reliability of the pre-survey data. The results showed that the Cronbach's $\alpha$ coefficients of the job satisfaction scale and the turnover intention scale were .861 and .836 , respectively. Because they were greater than .8 , they fall within the range of high reliability.

To make an exploratory factor analysis of the pre-survey data, SPSS 20.0 was used to obtain the KMO (Kaiser-MeyerOlkin) value and the Bartlett Test of Sphericity results. The KMO value of job satisfaction was .916, greater than .9. The salience value of the Bartlett Test of Sphericity was 0 , which was quite significant. These results showed that the presurvey sample was suitable for factor analysis.

SPSS 20.0 was used to perform the factor analysis of the sample data. The factor analysis method adopted principal component analysis and the maximum balance valuerotation method. The factor analysis obtained the total variance after the rotation, which added to $62.6 \%$ for 6 factors of job satisfaction and had good explanatory ability for the entire structure. The single-dimension structure of turnover intention was obtained with a total variance of $55.5 \%$, which had good explanatory ability for the entire structure. 
Table 1. Orthogonal rotation factor score.

\begin{tabular}{|c|c|c|c|c|c|c|}
\hline \multirow{2}{*}{$\begin{array}{l}\text { Dimensions } \\
\text { Salary and welfare }\end{array}$} & \multicolumn{6}{|c|}{ Items and Factor score } \\
\hline & A32 & A29 & A13 & A1 & A26 & A24 \\
\hline & 0.696 & 0.695 & 0.691 & 0.666 & 0.65 & 0.561 \\
\hline \multirow[t]{2}{*}{ Leader behavior } & A4 & A11 & A15 & A2 & A22 & \\
\hline & 0.818 & 0.765 & 0.581 & 0.569 & 0.427 & \\
\hline \multirow[t]{2}{*}{ Personal growth } & A6 & A16 & A17 & A7 & A34 & \\
\hline & 0.669 & 0.661 & 0.617 & 0.449 & 0.402 & \\
\hline \multirow[t]{2}{*}{ Work itself } & A33 & A35 & A14 & A9 & & \\
\hline & 0.804 & 0.624 & 0.603 & 0.535 & & \\
\hline \multirow[t]{2}{*}{ Interpersonal relationships } & A27 & A20 & A12 & A7 & & \\
\hline & 0.767 & 0.64 & 0.559 & 0.508 & & \\
\hline \multirow[t]{2}{*}{ Job competency } & A19 & A25 & A28 & & & \\
\hline & 0.88 & 0.857 & 0.421 & & & \\
\hline \multirow[t]{2}{*}{ Turnover intention } & C3 & C1 & C4 & $\mathrm{C} 2$ & & \\
\hline & 0.861 & 0.801 & 0.79 & 0.779 & & \\
\hline
\end{tabular}

Note: Items whose coefficients were less than .4 were removed

According to the data in Table 1 , the contribution range of the items designed by the scale and the corresponding dimensions was between .402 and .88 , reaching the designed critical level of the questionnaire. The results of the presurvey indicated that job satisfaction and turnover intention scale had good structural validity.

The reliability and validity analysis of the pre-survey data indicated that the job satisfaction scale and turnover intention scale proposed in this paper for early-career employees have good reliability and structural validity that will reflect the real relationship between job satisfaction and turnover intention for early-career employees.

\section{Formal survey}

To ensure the extensiveness and representativeness of the research, this study selected early-career employees en- gaged in, for example, communication services, petrochemical processing, and manufacturing industries as research subjects. We selected 30 enterprises located in Shandong Province, Shanghai, and Jiangsu Province. To improve accuracy, the survey was conducted in a secret-ballot manner. With the help of personnel from the enterprises' human resources departments, the questionnaires were distributed to employees of various departments using stratified random sampling, and special recycling bins were set up to recover the questionnaires. Of the 600 questionnaires that were distributed, 460 were received back. Among the 460, 418 were valid questionnaires, yielding a valid return rate of $69.7 \%$. The results of the sample demographic analysis are shown in Table 2.

Table 2. Demographic analysis.

\begin{tabular}{|c|c|c|c|c|}
\hline Statistics dacontent & & Sample size & Percentage $(\%)$ & Cumulative percentage $(\%)$ \\
\hline \multirow[t]{2}{*}{ ender } & Male & 166 & 39.8 & 39.8 \\
\hline & Female & 252 & 60.2 & 100 \\
\hline \multirow{2}{*}{ Marital status } & Single & 153 & 36.6 & 36.6 \\
\hline & Married & 265 & 63.4 & 100 \\
\hline \multirow[t]{5}{*}{ Age (years) } & Under 25 & 39 & 9.3 & 3.9 \\
\hline & $25-28$ & 136 & 32.5 & 41.8 \\
\hline & $28-30$ & 121 & 28.9 & 70.7 \\
\hline & Over 30 & 123 & 29.4 & 100 \\
\hline & $1-3$ years & 81 & 19.4 & 19.4 \\
\hline \multirow{4}{*}{ Length of service } & $3-5$ years & 131 & 31.3 & 50.4 \\
\hline & $5-8$ years & 128 & 30.6 & 81.3 \\
\hline & Over 8 years & 81 & 19.4 & 100 \\
\hline & High school students or below & 29 & 6.9 & 6.9 \\
\hline \multirow{3}{*}{ Education level } & Diploma students & 128 & 30.6 & 37.5 \\
\hline & undergraduates & 220 & 52.6 & 90.1 \\
\hline & Graduate students or above & 41 & 9.8 & 100 \\
\hline \multirow[t]{4}{*}{ Position } & ordinary workers & 363 & 86.8 & 86.8 \\
\hline & Frontline manager & 44 & 10.5 & 97.3 \\
\hline & Middle managers & 9 & 2.2 & 99.5 \\
\hline & Senior managers & 2 & 0.5 & 100 \\
\hline
\end{tabular}


The statistical results showed that male employees and female employees represented $39.8 \%$ and $60.2 \%$, respectively, of the total employees surveyed. Single employees and married employees represented $36.6 \%$ and $63.4 \%$ Employees under 30 years old represented $70.7 \%$ of the total. Surveyed employees with length of service of less than 8 years represented $81.3 \%$ of the total. In terms of education, employees with an undergraduate education background or above accounted for $62.4 \%$ of the total. This dataset had the basic characteristics of early-career employees defined in this paper. Therefore, the dataset was suitable for the research.

\section{Statistical analyses}

Before the structural equation model is used, it is necessary to judge whether the model can be identified, which is the key to deciding there exists a solution to the model. According to the number of variables and equations in the model, structural equation models can be classified into three categories: unidentifiable, exactly identifiable and excessively identifiable. For the model in this paper, there were 19 observational variables and 8 latent variables. Therefore, the minimum sample size was $19+19+8+8=54$. The number of valid samples was 418 , far greater than the number required by the minimum sample size; thereby, the model is identifiable.

The analysis was carried within the framework of Structural Equation Modeling (SEM), using the AMOS 20.0 statistical analysis software. Preliminarily, we tested a measurement model to determine whether the observed variables served as adequate indicators of the latent variables and supported the construct validity of the measures (Anderson \& Gerbing, 1988). Subsequently, The structural equation model for job satisfaction and turnover intention was constructed and the influence of job satisfaction on turnover intention was tested according to the hypothesis in this paper. The structural equation model is shown in Figure 1.

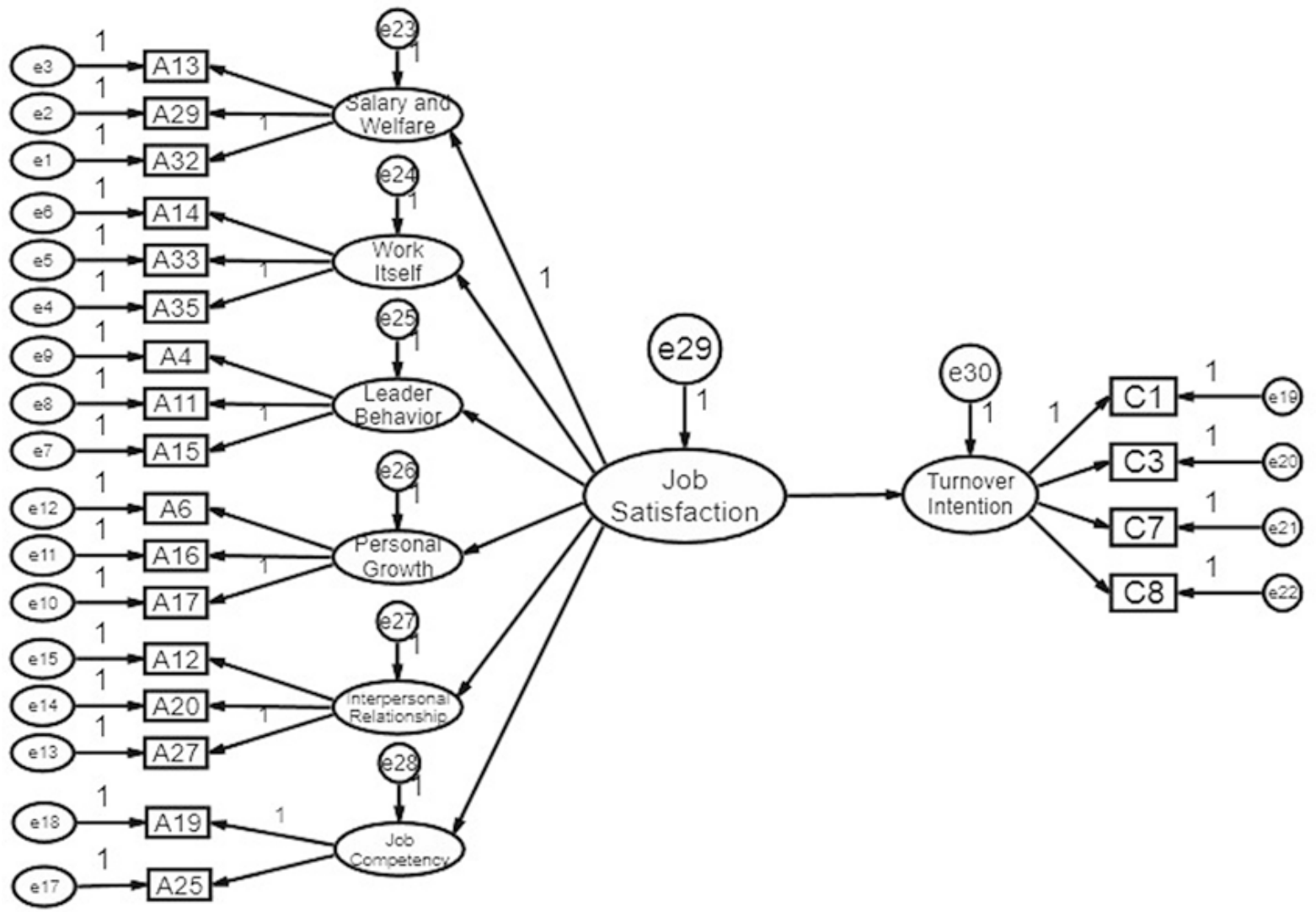

Figure 1. The structural equation model. 


\section{Results}

\section{Descriptive statistics}

SPSS 20.0 was employed to derive the descriptive statistical analysis of the variables and the correlation matrix between the variables as shown in Table 3.
Through descriptive statistical analysis and the correlation matrix, the correlation coefficients between employee job satisfaction and its six dimensions and turnover intention were judged to be in the range of -.614 and -.221, and they passed the significance test $(p<.01)$. To verify further the influence of job satisfaction on turnover intention, the structural equation model was constructed to test the hypothesis of the research.

Table 3. Descriptive statistical results of variables and the correlation matrix.

\begin{tabular}{|c|c|c|c|c|c|c|c|c|c|c|}
\hline & Mean & S.D. & SW & WI & LB & PG & IR & $\mathrm{JC}$ & JS & TI \\
\hline$\overline{\mathrm{SW}}$ & 3.1 & 0.93 & 1 & & & & & & & \\
\hline WI & 3.7 & 0.73 & $.66^{* * * *}$ & 1 & & & & & & \\
\hline LB & 4.0 & 0.69 & $.39^{\text {**** }}$ & $.41^{* * * *}$ & 1 & & & & & \\
\hline PG & 3.6 & 0.77 & $.62^{* * *}$ & $.60^{* * *}$ & $.50^{* * *}$ & 1 & & & & \\
\hline IR & 3.6 & 0.77 & $.42^{* * *}$ & $.37^{* * *}$ & $.45^{* * *}$ & $.46^{* * *}$ & 1 & & & \\
\hline $\mathrm{JC}$ & 3.2 & 1.01 & $.09^{*}$ & .07 & .07 & $.19^{* * *}$ & $.29^{* * *}$ & 1 & & \\
\hline JS & 3.5 & 0.56 & $.77^{* * * *}$ & $.73^{* * *}$ & $.65^{* * *}$ & $.80^{* * *}$ & $.72^{* * *}$ & $.47^{* * *}$ & 1 & \\
\hline TI & 2.4 & 0.81 & $-.50^{* * *}$ & $-.55^{* * *}$ & $-.34^{* * *}$ & $-.52^{* * *}$ & $-.43^{* * *}$ & $-.22^{* * *}$ & $-.61^{* * *}$ & 1 \\
\hline
\end{tabular}

Note: SW, Salary and welfare; WI, Work itself; LB, Leader behavior; PG, Personal growth; IR, Interpersonal relationships; JC, Job competency; JS, Job satisfaction; TI, Turnover intention; *indicates $\mathrm{p}<.5$, ***indicates $\mathrm{p}<.01$.

\section{Measurement model}

With reference to available studies, this research on the structure of job satisfaction proposes a 6-dimension structural model of job satisfaction. Through confirmatory factor analysis, the dimensions constituting job satisfaction were tested. The models included the following: a seven-factor model (a higher order factor and six first-order factors) and a single-factor model (all items converged on one dimension), a six-factor Model A (work itself and personal growth were incorporated into a single factor), a six-factor Model B (salary and welfare and personal growth were incorporated into a single factor), a six-factor Model C (work itself and salary and welfare were incorporated into a single factor), and a five-factor model (work itself, personal growth, and salary and welfare were incorporated into a single factor). Through comparing the fitting index of each model, the optimal model was selected. The results of the confirmatory factor analysis are shown in Table 4.

Table 4. Results of the confirmatory factor analysis.

\begin{tabular}{lccccccccc}
\hline & $\chi^{2}$ & $\mathrm{df}$ & $\chi^{2} / \mathrm{df}$ & GFI & AGFI & CFI & RMR & RMSEA & P \\
\hline 1 Single-factor Model & 1225 & 189 & 6.485 & .749 & .693 & .711 & .088 & .115 & .00 \\
2 Six-factor Model A & 347.2 & 114 & 3.045 & .909 & .878 & .911 & .059 & .070 & .00 \\
3 Six-factor Model B & 383.6 & 114 & 3.365 & .895 & .860 & .897 & .062 & .075 & .00 \\
4 Six-factor Model C & 339.8 & 114 & 2.981 & .910 & .879 & .913 & .055 & .069 & .00 \\
5 Seven-factor Model & 300.6 & 113 & 2.660 & .923 & .895 & .928 & .057 & .063 & .00 \\
Critical value & & & $1-3$ & $>.9$ & $>.9$ & $>.9$ & $<.06$ & $<.08$ & $<.05$ \\
\hline
\end{tabular}

The results of the confirmatory factor analysis indicate that the fit indexes of the seven-factor model were $\chi^{2}=$ 300.6, $\mathrm{df}=113, \chi^{2} / \mathrm{df}=2.66, G F I=.923, \mathrm{AGFI}=.895$, $\mathrm{CIF}=.925, \mathrm{RMR}=.057$, and RMSEA $=.063$. Compared with the other four models, this model's goodness-of-fit indexes, all reaching or approaching the critical values, were better than were those of the other fours. The composite reliability (CR) value of the second-order factor job satisfaction was .87 , and the average variance extracted (AVE) was .56. The CR value of the first-order factor salary, welfare satisfaction, was .84, and the AVE value was .63. The CR value of leader behavior satisfaction was .75 , and the AVE value was .51. The CR value of personal growth was .75, and the AVE value was .50. The CR value of job satisfaction was .50, and the AVE value was .74. The CR value of interpersonal relationships was .60 , and the AVE value was .33. The CR value of job competency was .75, and the AVE value was .60. The CR value of turnover intention was .85 , and the AVE value was .56. The seven-factor model better fit the actual data. Therefore, this research selected the seven-factor model as the optimal model. The above results show that the job satisfaction scale and turnover intention scale had a high degree of intrinsic consistency and that the structure of the questionnaire was rational.

Based on the Measurement model analysis of the abovementioned scale, the job satisfaction and turnover intention scale adopted in this research has good validity. Therefore, it is an acceptable scale and can be used for further study. 


\section{Test of the Common Method Bias}

Because the subjects of job satisfaction and turnover intention in this research were influenced by corporate culture, working background, and personal factors, a common method variance might exist. This possibility requires a control and test for common method variance bias. This research adopted the procedure control method. First, the order effect of the scale was ruled out, and the anonymity of subjects was protected. Next, some reverse questions were set up in the scale. The procedure control method was insufficient to eliminate common method variance bias; therefore, the data analysis stage should be tested for common method bias. This paper adopted the non-measurable latent factor method to test the data. The detailed steps are as follows: In the structural equation model, the common method variance is considered a latent variable. All marking variables are allowed to be loaded on this latent variable, and the goodnessof-fit indexes of the model before and after the control are compared. Existence of a common method factor model whose fit indices are better than are those of the noncommon method factor models would indicate that there is an obvious bias of the common method variance. The main fit indices of the model before the control and after the control are shown in Table 5.

Table 5. Comparison of fit indexes before and after the control.

\begin{tabular}{lcccccccc}
\hline Fit measure & $\chi^{2}$ & DF & GFI & AGFI & CFI & RMR & RMSEA & P \\
\hline Before the control & 224 & 104 & .941 & .913 & .954 & .040 & .053 & .00 \\
After the control & 164 & 87 & .956 & .922 & .970 & .032 & .046 & .00 \\
\hline
\end{tabular}

Table 5 shows that the Chi square value $\left(\chi^{2}\right)$ underwent a significant change. In the table, $\Delta \chi^{2}=80$; considering that $\Delta \chi^{2}$ was systematically influenced by the size of the sample, when the fit indices of the model before and after the control were compared, the changes of other fit indices should be referenced. The change of the fit index values GFI, CFI, AGFI, RMR and RMSEA of the model after the control did not exceed 0.02 , indicating that the improvement of the fit goodness of the model added with the common method factor was not obvious. ${ }^{[27]}$ Additionally, the values indicated that the common method variance of the sample data was not significant and was within the acceptable range.

\section{Structural model}

The statistical analysis software AMOS 20.0 was employed to derive the CMIN/DF of the model, which stood at 2.466. GFI, AGFI, CFI and PGFI were .906, .881, .926, and .714, respectively. RMR and RMSEA were .056 and .059. All model values reached the critical standard except that AGFIS is lightly lower than critical standard. The model has good fitness and can be further tested.

AMOS 20.0 was used for the valuation calculation of the Structural model to derive the influence on the higher-order factor of job satisfaction by the various dimensions of job satisfaction and the path coefficient between job satisfaction and turnover intention as well as their significance test result. The results of the significance test are shown in Table 6 .

Table 6. Path coefficients of each dimension and the significance test.

\begin{tabular}{|c|c|c|c|}
\hline Path & Standard load & C.R. & $p$ value \\
\hline Salary and welfare <---Job Satisfaction & .843 & - & - \\
\hline Work itself <--- Job Satisfaction & .885 & 12.88 & $.00^{* * *}$ \\
\hline Leader behavior <--- Job Satisfaction & .652 & 8.44 & $.00^{* * *}$ \\
\hline Personal growth <--- Job Satisfaction & .918 & 10.90 & $.00^{* * *}$ \\
\hline Interpersonal relationships $<---$ Job Satisfaction & .753 & 7.92 & $.00^{* * *}$ \\
\hline Job competency $<---$ Job Satisfaction & .214 & 2.21 & $.00^{* * *}$ \\
\hline Turnover Intention <--- Job Satisfaction & .730 & 1079 & $.027^{*}$ \\
\hline
\end{tabular}

Note: *indicates $\mathrm{p}<.5, * * *$ indicates $\mathrm{p}<.01$

In Table 6, the standard loads of six dimensions, namely job competency, interpersonal relationships, personal development, work itself, leader behavior, and salary and welfare, on job satisfaction were $.214, .753, .918, .885, .652$ and .843 , respectively. The six dimensions' influence on the higher order factor, namely job satisfaction, was significant below the .05 level, and the order of the influence was personal growth, salary and welfare, work itself, interpersonal relationships, leader behavior and job competency.
The six hypotheses proposed in this research, namely H1a, H1b, H1c, H1d, H1e and H1f were empirically supported.

In Table 6, the C.R. value of job satisfaction and turnover intention was $10.791, \mathrm{P}<.001$, and the standardized path coefficient was -.730 . The results indicate that job satisfaction has a significantly negative effect on turnover intention; thus, Hypothesis $\mathrm{H} 2$ is empirically supported. 


\section{Discussion and Conclusions}

This study took Chinese early-career employees as research subjects, and 418 valid questionnaires were collected using the department stratified random sampling method. The factor analysis method and the structural equation model were employed to perform an empirical study of the influencing factors on employee job satisfaction and the relationship between job satisfaction and turnover intention. The following conclusions are obtained.

(1) The paper involves two variables, namely job satisfaction and turnover intention. The results of the pre-survey show that the Cronbach's coefficients of the job satisfaction scale and the turnover intention scale were .861 and .836 , respectively, greater than .8 and falling within the highreliability scope. The results of the exploratory factor analysis show that job satisfaction and turnover intention have good structure validity, which can reflect the real situation of job satisfaction and turnover intention of early-career employees.

(2) Job satisfaction proposed in this study is based on the Minnesota Satisfaction Questionnaire. Combined with domestic studies on job satisfaction, this research performed a more complete and precise study of the constituent dimensions of job satisfaction from a micro perspective. A sevenfactor job satisfaction model is advanced, including one high-order factor (job satisfaction) and six first-order factors (salary and welfare, work itself, leader behavior, personal growth, interpersonal relationships and job competence). The results of the confirmatory factor analysis show that the seven-factor job satisfaction model has a better goodness of fit compared with the single-factor model and the six-factor models and can reflect better the make-up of job satisfaction of early-career employees faithfully. Job satisfaction, which is a high-order factor, consists of 6 dimensions: salary and welfare, work itself, leader behavior, personal growth, interpersonal relationships and job competency. This study, compared with the five-dimension job satisfaction model proposed by Zhang and Liao (2009), increased the job competency dimension. This increase is primarily because the research subjects in this study are early-career employees whose working experience is inadequate and whose career anchors are unstable; therefore, satisfaction with job competency is an essential factor.

Job satisfaction, as a high-order factor, consists of 6 firstorder factors. Among them, the maximum load coefficient of personal growth's influence on job satisfaction reaches .918. Next come salary and welfare, work itself, interpersonal relationships, and leader behavior. Job competency's influence on job satisfaction is the smallest, with a factor load coefficient of only .214. This conclusion is consistent with the conclusion of Li (2015)'s research on the job satisfaction of college teachers. However, Chinese scholars Zhang and Liao (2009)'s research shows that salary and welfare's influence on job satisfaction is the largest; next come job itself, promotion, relationships with co-workers and supervision. The causes for this type of difference might be that early-career employees focus more on their personal development but less on salary and welfare. Early-career employees are in the learning and developing stage of their careers, and their job satisfaction in terms of job competency is rather low. Employees earlier in their careers are willing to improve their own working capacity through learning to reach job competence.

(3) The results of the path structure analysis using the structural equation model indicate that job satisfaction of early-career employees has a significantly negative influence on turnover intention. The influence of job satisfaction on turnover intention has always been a hot spot for academic study, and scholars usually consider job satisfaction as the predictive variable of turnover intention. The results of this study show that for early-career employees, the standardized path coefficient of their job satisfaction's influence on their turnover intention is -.730 , and the influence effect is greater than that of -.35 obtained by Ye, Wang and Lin (2005), indicating that job satisfaction of early-career employees has a greater influence on their turnover intention. The main cause might be due to reasons such as the instability of their career anchors, short in-service times, or low organizational commitment; therefore, when they have dissatisfactions toward their current work, it is easier for them to consider quitting.

Through a study of the literature available, combined with the Chinese domestic background and characteristics of early-career employees, this paper has advanced a sixdimensional model of job satisfaction for early-career employees. Through empirical results, the rationality of job satisfaction as a high-order factor is confirmed, and job satisfaction's significantly negative effect on turnover intention is proved. Due to the constraints of manpower and material resources, some limitations remain for this research. Although this paper has advanced a six-dimensional model, it has not considered all influencing factors. The research data came from Chinese companies and enterprises, and the industries investigated included manufacturing, petrochemical processing, communication and other service industries, which are influenced by the Chinese society and culture; therefore, the need to avoid common method variance is inevitable.

This paper's classification of dimensions of job satisfaction has general significance. Future studies can be based on these six dimensions and a job satisfaction model that includes more dimensions could be developed. In addition, this research studied the direct role of job satisfaction of early-career employees in turnover intention; however, it did not consider an intermediary variable between job satisfaction and turnover intention. In a future study, organizational variables and personal variables, for example, organizational commitment and a psychological variable, could be included as intermediary or regulating variables, and corresponding control variables could be incorporated to exclude relevant influencing factors to obtain more-representative conclusions. 
Acknowledgements.- This test is subsidized by transverse project of "A survey of the relationship between employee satisfaction and

\section{References}

Alegre, I., Marta, M. M., \& Jasmina, B. M. (2016). Antecedents of employee job satisfaction: Do they matter? Journal of Business Research, 69, 13901395. doi: 10.1016/j.jbusres.2015.10.113

Alina, M., \& Simona, E. (2013). Pre-university teachers' professional satisfaction. Procedia- Social and Behavioral Sciences, 78, 110-114. doi: 10.1016/j.sbspro.2013.04.261

Chen, Y., \& Tang, G. Y. (2015). An analysis of the effect and mechanism of upward Ingratiation on employee's job satisfaction. Forecasting, 6, 2127. doi: $10.11847 /$ fj.34.6

Esra, A., Ümit, A., Serhat, E., \& Kültigin, A. (2013). Does personorganization fit moderate the effects of affective commitment and job satisfaction on turnover intentions?. Social and Behavioral Sciences, 99, 274-281. doi: 10.1016/j.sbspro.2013.10.495

Fachrunnisa, O., \& Adhiatma, A. (2014). The role of work place spirituality and employee engagement to enhance job satisfaction and performance. International Journal of Organizational Innovation , 7, 15-35.

Faris, A., Mary, T. Q. G., Scott, R. Z., \& Joyce, J. F. (2014). Job satisfaction and turnover intention among Jordanian nurses in psychiatric units. International Journal of Mental Health Nursing, 23, 460-467. doi: $10.1111 /$ inm. 12070

Galit, M. (2013). Empirical exploration of the relationship between emotional intelligence, perceived organizational justice and turnover intentions. Employee Relations, 35, 441-455. doi: 10.1108/ER-05-2012-0041

Hoppock, R. (1935). Job Satisfaction. American, New York: Harper.

Jiang, Y., Qian, Q. Z., \& Yan, C. Y. (2006). A study on the structure model of teachers' job satisfaction. Psychological Science, 1, 162-164. doi: 10.3969/j.issn.1671-6981.2006.01.044

Kalleberg, A. L., \& Loscocco, K.A. (1983). Aging, values, and rewards: explaining age differences in job satisfaction. American Sociological Review, $48,78-90$.

Kenny, P., Reeve, R., \& Hall, J. (2016). Satisfaction with nursing education, job satisfaction, and work intentions of new graduate nurses. Nurse Education Today, 36, 230-235. doi:10.1016/j.nedt.2015.10.023

Laschinger, H., \& Spence, K. (2012). Job and career satisfaction and turnover intentions of newly graduated nurses. Journal of Nursing Management, 20, 472-484. doi: 10.1111/j.1365-2834.2011.01293.x

Lee, B. Y., Wang, J., \& Weststar, J. (2015). Work hour congruence: the effect on job satisfaction and absenteeism. The International Journal of $\mathrm{Hu}$ man Resource Management, 26, 657-675. doi: dx.doi.org/10.1080/09585192.2014.922601

Li, H. R., Wang, C. X., \& Chen, S. B. (2015). On the factors contributing to the job satisfaction of new generation faculty in university. Social Sciences in Zhejiang, 4, 145-150. doi: 10.14167/j.zjss.2015.04.020

Liu, F. Y., \& Zhang, J. C. (2004). The validity of employee's job satisfaction survey questionnaire and the influence factors on the job satisfaction from civilian enterprise's Employees. Nankai Business Review, 3, 98-104. doi: 10.3969/j.issn.1008-3448.2004.03.018

Liu, P. Q., Wang, X., Liu, R., \& Wei, X. (2013). The effects of leadership styles on workers' job satisfaction: a mediating approach of employee relations. Chinese Journal of Management Science, S1, 75-80.

Martínez, I. M., \& Cifre, E. (2016). Individual and group antecedents of job satisfaction: a one-lab multilevel study. anales de psicologia, 32, 565-570. doi: dx.doi.org/10.6018/analesps.32.2.216801

Melinde, C., \& Nisha, H. (2014). Emotional intelligence as a predictor of employees' career adaptability. Journal of Vocational Behavior, 84, 90-97. doi: 10.1016/j.jvb.2013.09.001 turnover intention (HX2014)" and general protect of National Nature and Science Fund(71371107).

Scanlan J.N., \& Still, M. (2013). Job satisfaction, burnout and turnover intention in occupational therapists working in mental health. Australian occupational therapy journal, 60, 310-318. doi: 10.1111/1440-1630.12067

Peng, C. Y. (2008). An empirical study on moderating role of occupational commitment on relationship of the psychological contact of knowledge worker with job satisfaction and intention to leave. Science of Science and Management of $S \& T, 12,167-171$.

Porter, L. W., Steers, R. M., Mowday, R. T., \& Boulian, P. V. (1974). Organizational Commitment, Job Satisfaction and turnover among psychiatric technicians. Journal of Applied Psychology, 59, 603-609.

Richard, F. G., Joseph, L. L., \& Billy, B. (2001). Job satisfaction, life satisfaction, and turnover intent among food-service managers. Cornell Hotel and Restaurant Administration Quarterly, 42, 28-37. doi: 10.1016/S00108804(01)80036-7

Risman, K. L., Erickson, R. J., \& Diefendorff, J. M. (2016). The impact of person-organization fit on nurse job satisfaction and patient care quality. Applied Nursing Research, 31, 121-125. doi: 10.1016/j.apnr.2016.01.007

Scanlan, J. N., \& Still, M. (2013). Job satisfaction, burnout and turnover intention in occupational therapists working in mental health. Australian Occupational Therapy Journal, 60, 310-318. doi: 10.1111/1440-1630.12067

Shen, W. Y., \& Zhu, J. W. (2012). Enterprise job satisfaction and turnover intention. Social Scientist, 12, 80-83. doi: 10.3969/j.issn.10023240.2012.12.019

Vermeeren, B., Kuipers, B., \& Steijn, B. (2014). Does leadership style make a difference linking HRM, job satisfaction, and organizational performance. Review of Public Personnel Administration serial online, 34, 174-195. doi: 10.1177/0734371X13510853

Vroom, H. V. (1962). Ego-involvement, job satisfaction and job performance. Personnel Psychology, 15, 159-177.

Wang, J. Y. (2012). China's labor participation age pattern change and its future labor supply structure analysis. Social Sciences in Guangdong, 2, 6-14.

Wang, X. L., Ma, L., \& Zhang, M. (2014). Person-job fit, job satisfaction and turnover intention: the moderating effect of the only children in China. Chinese Journal of Management, 5, 691-695. doi: 10.3969/j.issn.1672-884x.2014.05.010

Wang, Z., \& Zhang, L. (2010). An empirical study on relations among person-organization fit, job satisfaction and turnover intention. Chinese Journal Management, 3, 379-385. doi: 10.3969/j.issn.1672884X.2010.03.011

Weiss, D. J., Dawis, R. V., \& England, G. W. (1967). Manual for the Minnesota satisfaction questionnaire. Minnesota Studies in Vocational Rehabilitation, 22, 120.

Xiong, M. L., Sun, J. M., \& Koo, L. C. (2008). A study on correlation between job satisfaction, organizational identification and turnover intention. Journal of Business Economics, 6, 34-40. doi: 10.3969/j.issn.10002154.2008.06.006

Ye, R. S., Wang, Y. Q., \& Lin, Z. Y. (2005). An empirical study on the influence of job satisfaction, organizational commitment on state-owned enterprises' employees' turnover. Management World, 3, 122-125.

Zhang, S. J., \& Liao, J. Q. (2007). An empirical study on the influences of dimensions of employee job satisfaction on total job satisfaction. Science of Science and Management of $S \& T, 8,184-188$. doi: 10.3969/j.issn.1002-0241.2007.08.036

Zhou, S. (2009). After the 80 employees "career" analysis 80. Management World, 4, 184-185.

(Article received: 02-10-2016; revised: 07-04-2016; accepted: 16-05-2016) 


\section{Supplementary Table 1}

\begin{tabular}{|c|c|c|}
\hline \multicolumn{3}{|c|}{ Job satisfaction scale (in dimensions) } \\
\hline \multirow{6}{*}{ Salary and welfare } & A1 & I feel satisfied about the welfare of the company in the same industry. \\
\hline & A13 & I feel my work has been duly rewarded. \\
\hline & A24 & The moment I think about the salary the organization pays me, I feel I am not adequately valued. (R) \\
\hline & A26 & Welfare and benefits in our unit are fair. \\
\hline & A29 & The salary system of the company can stimulate me to work hard. \\
\hline & A32 & I feel satisfied about my opportunity for a pay rise. \\
\hline \multirow{6}{*}{ Work itself } & A3 & I feel fulfilled and proud of the work I am engaged in. \\
\hline & A9 & I sometimes feel that my work is meaningless. (R) \\
\hline & A14 & I can derive pleasure from my job. \\
\hline & A23 & My job can make me happy. \\
\hline & A33 & My work supplies me with a stable job. \\
\hline & A35 & I like my current job very much. \\
\hline \multirow{6}{*}{ Leader behavior } & A4 & My superior is very capable. \\
\hline & & My superior has no interest in his subordinates. (R) \\
\hline & A11 & I like my superior. \\
\hline & A15 & My superior is fair to subordinates. \\
\hline & A21 & My superior is seldom considerate to subordinates. $(\mathrm{R})$ \\
\hline & $\mathrm{A} 22$ & My superior seldom makes wrong decisions. \\
\hline \multirow{5}{*}{ Personal growth } & & As long as I do a good job, I will have promotion prospects. \\
\hline & A10 & I can improve ability during the training process of the company. \\
\hline & A16 & I feel satisfied with my promotion opportunity. \\
\hline & A17 & I can constantly get new knowledge and experience from my work. \\
\hline & A34 & I am willing to accept difficult work and challenges. \\
\hline \multirow{6}{*}{$\begin{array}{l}\text { Interpersonal } \\
\text { relationships }\end{array}$} & & I feel very happy working with my colleagues. \\
\hline & A12 & There is a lot of responsibility shirking and bickering in the workplace. (R) \\
\hline & A18 & I am satisfied with the way in which colleagues deal with each other in the company. \\
\hline & A20 & When pressures and difficulties arise in my work, my colleagues can offer me help and support. \\
\hline & A27 & Due to the limited capacity of my colleagues, I have to make more efforts in my work (R). \\
\hline & A30 & My role in the team can be recognized and have a positive influence. \\
\hline \multirow{5}{*}{ Job competence } & & While doing my job well, I have a lot of time to communicate with my relatives and friends. \\
\hline & A19 & My work pressure makes me have no time to do what I want. \\
\hline & A25 & The operation procedure of the company has made me very exhausted \\
\hline & A28 & My workload constantly surpasses my endurance (R). \\
\hline & A31 & The rules and regulations in our work unit make it difficult for one to do a good job (R). \\
\hline \multicolumn{3}{|c|}{ Turnover intention scale } \\
\hline \multirow{4}{*}{ Turnover intention } & C1 & I consider leaving my current enterprise one day. \\
\hline & $\mathrm{C} 2$ & I constantly want to quit the current job. \\
\hline & & I try looking for a suitable new job next year. \\
\hline & $\mathrm{C} 4$ & I think my own prospects might not be good if I continue to stay in the company. \\
\hline
\end{tabular}

